\title{
Front Matter: Volume 11789
}

, "Front Matter: Volume 11789," Proc. SPIE 11789, Fourth International Seminar on Photonics, Optics, and Its Applications (ISPhOA 2020), 1178901 (12 March 2021); doi: 10.1117/12.2595909

SPIE Event: Fourth International Seminar on Photonics, Optics, and Its Applications (ISPhOA 2020), 2020, Sanur, Indonesia 


\title{
Fourth Intemational Seminar on Photonics, Optics, and Its Applications (ISPhOA 2020)
}

\author{
Agus Muhammad Hatta \\ Aulia Nasution \\ Ruri Agung Wahyuono \\ Editors
}

\section{1-2 Dec ember 2020 \\ Online Only, Indonesia}

Organized by

Institut Teknologi Sepuluh Nopember (Indonesia)

Universitas Airlangga (Indonesia)

Institut Teknologi Bandung (Indonesia)

Universitas Indonesia

Univeritas Brawijaya (Indonesia)

Universitas Udaya na (Indonesia)

Universitas MaChung (Indonesia)

\section{Sponsored by}

Direc torate of Research and Community Service

The Optical Society (United States)

Intemational Commission for Optics (ICO)

PTHORIBA Indonesia

PT Senviam Abadi Mumi (Ind onesia)

Published by

SPIE 
The papers in this volume were part of the technical conference cited on the cover and title page. Papers were selected and subject to review by the editors and conference program committee. Some conference presentations may not be available for publication. Additional papers and presentation recordings may be available online in the SPIE Digital Library at SPIEDigita lLibrary.org.

The papers reflect the work and thoughts of the authors and are published herein as submitted. The publisher is not responsible for the validity of the information or for any outcomes resulting from reliance thereon.

Please use the following format to cite material from these proceedings:

Author(s), "Title of Paper," in Fourth Intemational Seminar on Photonics, Optics, and Its Applications (ISPhOA 2020), edited by Agus Muhammad Hatta, Aulia Nasution, Ruri Agung Wahyuono, Proceedings of SPIE Vol. 11789 (SPIE, Bellingham, WA, 2021) Seven-dig it Artic le CID Number.

ISSN: 0277-786X

ISSN: 1996-756X (electronic)

ISBN: 9781510644120

ISBN: 9781510644137 (electronic)

Published by

SPIE

P.O. Box 10, Belling ham, Wa shington 98227-0010 USA

Telephone +1 3606763290 (Pa cific Time)· Fax +1 3606471445

SPIE.org

Copyright $@ 2021$, Society of Photo-O ptic al Instrumentation Engineers.

Copying of material in this book for intemal or personal use, or for the intemal or personal use of specific clients, beyond the fair use provisions granted by the U.S. Copyright Law is a uthorized by SPIE subject to payment of copying fees. The Transactional Reporting Service base fee for this volume is $\$ 21.00$ per article (or portion thereof), which should be paid directly to the Copyright Clearance Center (CCC), 222 Rosewood Drive, Danvers, MA 01923. Payment may also be made electronically through CCC Online at copyright.com. Other copying for republication, resale, advertising or promotion, or any form of systematic or multiple reproduction of any material in this book is prohibited except with permission in writing from the publisher. The CCC fee code is 0277$786 \mathrm{X} / 21 / \$ 21.00$.

Printed in the United States of America by Curran Associates, Inc., und er license from SPIE.

Public ation of record for individual papers is online in the SPIE Digital Library.

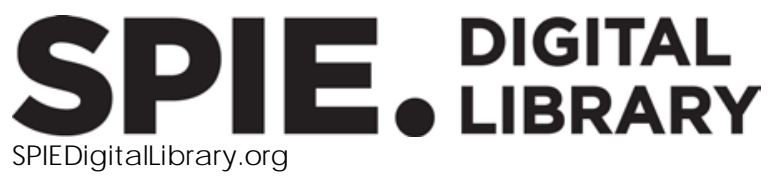

Paper Numbering: Proceedings of SPIE follow an e-First publication model. A unique citation identifier (CID) number is assigned to each article at the time of publication. Utilization of CIDs allows articles to be fully citable as soon as they are published online, and connects the same identifier to all online and print versions of the publication. SPIE uses a seven-digit CID article numbering system structured as follows:

- The first five digits correspond to the SPIE volume number.

- The last two digits indicate publication order within the volume using a Base 36 numbering system employing both numerals and letters. These two-number sets start with $00,01,02,03,04$, 05, 06, 07, 08, 09, 0A, 0B ... 0Z, followed by 10-1Z, 20-2Z, etc. The CID Number appears on each page of the manuscript. 


\section{Contents}

v Introduction

FOURTH INTERNATIONALSEMINAR ON PHOTONICS, OPICS, AND ITSAPPUCATIONS (ISPHOA 2020)

$1178902 \quad$ Understanding of the dynamics of watermolecules by using terahertz spectroscopy and its bio-applic ations (Invited Paper) [11789-29]

$1178903 \quad$ Elastography measurement for soft material using digital holography [11789-7]

1178904 Estimation of respiratory rate based on image processing using camera with pixel value analysis method [11789-9]

1178905 Reconstruction and regularization multi fiame super resolution on vegetation index NIR image [11789-11]

$1178906 \quad$ Improvement of digital phase shifting profilometry skin imaging by combination of fiequency and spatial filtering [11789-15]

1178907 Application of RGB-CCM and GLCM texture analysis to predict chlorophyll content in Vemonia amygdalina [11789-18]

1178908 Face detection and recognition in real-time photos with haar cascade and local binary pattem histogram for automatic door locking system [11789-23]

1178909 Low amplitude coherently coupled solitons in photorefractive polymers [11789-5]

11789 OA Modifying surface energy level of citric acid-based carbon dots with polyethylene [11789-6]

11789 OB Design of GaN-based optical switch fortelecommunic ation links [11789-14]

11789 OC Design of plastic optical fiber for soil moisture measurements as potential landslide detector [11789-22]

11789 OD Absomtion specta of edible oils on UV-visible-near infiared region [11789-24]

$11789 \mathrm{OE} \quad$ Use of a singlemode multimode singlemode fiber structure forapex cardiography monitoring [11789-27]

11789 OF Estimation of refractive index of eggshell in intact egg using terahert time-domain spectrosc opy [11789-4]

11789 0G Measurement of glucose concentrations in solid tissue phantom using diffuse refiectance technique in NIR region [11789-8] 
$11789 \mathrm{OH} \quad$ Non-invasive blood oxygenation monitoring from different sites of human body using diffuse reflectance spectroscopy: a feasibility study of diabetic foot monitoning [11789-16]

11789 ol Preliminary investigation on rice bran residue detection using ultraviolet fluorescence imaging [11789-17]

11789 0] Photodynamic potential of blue diode laser inactivation with chlorophyll photosensitisers in Pseudomonas aenuginosa and Staphylococcus aureus bacteria [11789-25]

11789 OK Wavelength identification of red betel leaf (piper crocatum), green betel leaf (piper betle l.) and black betel leaf (piper betle v.) using Ultraviolet-Visible (UV-Vis) spectroscopy method coupled with Principal Component Analysis (PCA) [11789-28]

$11789 \mathrm{OL} \quad$ Calibrating a non-contact and low-cost respiratory monitoring system based on Digital Comelation Technique [11789-3]

11789 OM Laser distance meter for cylindertank volume measurement system [11789-13]

11789 ON An a ltemative dic hromatic white LP light source for OOK-NRZ visible light communication system [11789-19]

1178900 Development of simple and low cost laser-based viscometer [11789-21]

11789 OP Object profiling using FMCW reflectometry with asymmetric method [11789-26] 


\section{Introduction}

First of all, I would like to cordia lly welc ome all of disting uished speakers, presenters, and all participants of ISPhOA 2020. Welc ome to this Virtual Seminar that is held for the first time due to pandemic COVID-19 that spreads worldwide, including in Indonesia. Even through facing a difficult situation due to the pandemic, thankfully we a re still a ble to organize this biennial seminar in 2020.

Thanks to all distinguished invited speakers that a re still committed to deliver their inspining lectures to this year's biennial event, as well as all authors that are contributing their valuable papers to be shared in this seminar. On behalf of all members of the Committee I would like to express my highest gratitude to your "never give up" spint to combating this difficult pandemic situation together. Of course... life must go on

Back to the seminar, this ISPhOA 2020 is the fourth biennial scientific seminar series, after its predecessors in 2014, 2016, and 2018. This sc ientific forum is dedicated to providing a venue for disc ussions, the sharing of expertise, and the hope to be an ideal place to build a strong network among the stake holders from Universities, R\&D C enters, Industries, and Govemment Offic ials that a re actively involved in the development of Optic sand Photonics. It is also hoped to promote the transfer of $R$ $\& D$ outcomes into applications that match with societal and industrial needs, particularly the ones a cross nationwide and ASEAN regions.

Light plays a vital role in our da ily lives and is a $n$ impera tive cross-cutting disc ipline of science in the 21st century. Optics, Photonics, and their applied light-based technologies have promoted sustainable developments and provide solutions to

global challenges in energy, education, agriculture and health. It has revolutionized medical cares, opened up intemational communication via the Intemet, and continues to be central to link the cultural, economic and political aspects in the global society. The UNESCO even had declared 16 May as the Intemational Day of Light, to yearly commemorate its important contributions in many aspects of human life.

I would like to thank all of our distinguished plenary speakers, that, even though in this diffic ult worldwide pandemic situation, have still committed to accept our previous invitation to share their novel and recent research achievements and expertise with otherpartic ipants of the seminar. Thanks a lso for the researchers and academicians that have sent their working papers to be shared and presented in the seminar forum. High appreciation is also dedicated to members of the Technical Committee, that have helped us to review and choose the submitted contributions that fulfil the scientific qua lity standards set for the seminar. 
To all of the sponsors from companies and societies in Optic sand Photonics (ICO, OSA, as well as OSA Indonesia Section) that give their valuable support to the successful organizing of the seminar. Last, but not least, many thanks to the Institut Teknologi Sepuluh Nopember, Faculty of Industrial Technology and Systems Engineering, and the Department of Engineering Physics for the total and endless support in facilitating the preparation and organizing of the seminar.

Finally on behalf of all presenters and partic ipants of ISPhOA 2020, I hope that you all will have a successful seminar and have nice, succ essful, and fruitful discussions and networking. We are looking forward to your coming contribution to the 5th Intemational Seminar on Photonics, Optic s and itsApplic ations (ISPhOA) 20220. See you again!

Agus Muhamad Hatta 